\title{
Control of powdery mildew (Leveillula taurica) on tomato by foliar sprays of liquid potassium silicate $\left(\mathrm{K}_{2} \mathrm{SiO}_{3}\right)$
}

\author{
Yusuf Yanar $^{1 *}$, Durdane Yanar ${ }^{1}$ and Nalf Gebologlu ${ }^{2}$ \\ ${ }^{1}$ Department of Plant Protection, Agricultural Faculty, Gaziosmanpasa University, 60250 Tokat, Turkey. \\ ${ }^{2}$ Department of Horticulture, Agricultural Faculty, Gaziosmanpasa University, 60250 Tokat, Turkey.
}

Accepted 21 March, 2011

\begin{abstract}
A foliar application of soluble silicon (liquid potassium silicate) was tested for the control of powdery mildew of tomato for 2 years in the field conditions on susceptible cultivar Alida F1. Powdery mildew in field-grown staked tomato, caused by Leveillula taurica was significantly controlled by a foliar spray of either $\mathrm{K}_{2} \mathrm{SiO}_{3}$ or Bayleton + sulfur. Potassium silicate applied on a 12 day schedule was highly protective against natural infection by the mildew fungus in the field conditions. The disease severity indexes (DSI) were $\mathbf{7 7 . 5}$ and $74.7 \%$ in control plots in 2006 and 2007, respectively, and were significantly different $(P<$ 0.05 ) from those in the $\mathrm{K}_{2} \mathrm{SiO}_{3}$ plots with 5.8 and $4.6 \%$ in 2006 and 2007, respectively. Potassium silicate concentration ( $1 \mathrm{~g} / 1 \mathrm{~L}$ water) used in the present study were not phytotoxic to plant foliage. The inhibitory effectiveness of potassium silicate makes it a useful biocompatible fungicide and possibly ideal foliar fertilizer for disease control in the field.
\end{abstract}

Key words: Powdery mildew, potassium silicate, fungicide, tomato.

\section{INTRODUCTION}

Tomato is among the most important vegetables grown by farmers in Tokat with an annual production of 450000 to 600000 ton/year (Anonymous, 2007). Tomatoes are mainly produced under open field conditions as staked tomato. Staked tomato cultivars are susceptible to a variety of pests and diseases. Powdery mildew of tomato is one of the economically important diseases that occurred in Turkey in recent years (Ozan and Maden, 2006). The causal fungus was identified as Leveillula taurica (Lév.) G. Arnaud according to Ozan and Maden (2006). This disease affects all above ground plant parts and reductions in growth and quality are the most important components of economic loss. It is widespread in the field grown with staked tomato in Tokat. Most growers in Tokat use repeated applications of fungicides for managing powdery mildew. Sulfur and synthetic fungicides have been the traditional option of control.

However, the extensive and prolonged use of synthetic fungicides has resulted in the development of resistance

${ }^{\star}$ Corresponding author. E-mail: yyanar@gop.edu.tr. Fax: +090356-2521488. in the fungus (Pasche et al., 2004). Alternative methods for disease management are expected by the public due to the increasing concern that fungicides may have negative impact on the environment and human health. In recent years, a number of studies have done experiment by using silicon $(\mathrm{Si})$ for the control of plant fungal diseases with promising results.

A review by Epstein (1999), discussed the role of silicon on plant disease control. Several studies have demonstrated that the severity of powdery mildew on cucumber, grape, strawberry and wheat, can be reduced through foliar or soil applications of potassium silicate (Lee et al., 2000; Yildirim et al., 2002; Be'langer et al., 2003; Kanto et al., 2006). Liquid potassium silicate applications have resulted in reduced severities of powdery mildew on strawberry (Kanto et al., 2006) and grape (Reynolds et al., 1996; Yildirim et al., 2002). Foliar and root applications of $\mathrm{Si}$ reduced the severity of the powdery mildew in cucumber leaves (Lee et al., 2000). Powdery mildew colony number in grape leaves was reduced to $16 \%$ of the control leaves when foliar $\mathrm{Si}$ sprays were used (Yildirim et al., 2002). The objective of this work was to examine the effects of foliar applications of liquid potassium silicate on the severity of $L$. taurica on 
Table 1. Treatments and concentrations of the $\mathrm{KSiO}_{3}$ and synthetic fungicides.

\begin{tabular}{ll}
\hline \multicolumn{1}{c}{ Treatment } & \multicolumn{1}{c}{ Concentration } \\
\hline${ }^{1}$ Thiovit 80\% WP alternate with Bayleton WP 5 & $3 \mathrm{~g} / 1 \mathrm{~L}+0.5 \mathrm{~g} / 1 \mathrm{~L}$ \\
Potassium silicate $\left(\mathrm{K}_{2} \mathrm{SiO}_{3}\right)$ & $1 \mathrm{~g} / 1 \mathrm{~L}$ \\
Untreated control & Tap water (applied until run off) \\
\hline${ }^{1}$ Thiovit $80 \%$ WP (sulfur) (Syngenta Grubu San.Ltd.Şti); & Bayleton WP 5 (triadimenol) (Bayer \\
San.Ltd.Şti).
\end{tabular}

Table 2. Disease severity (DS), controll efficiency and disease severity index (DSI) in comparison with untreated control with five applications of sulfur + triadimenol and $\mathrm{KSiO}_{3}$ on the powdery mildew severity of tomato under field conditions.

\begin{tabular}{lcccccc}
\hline \multirow{2}{*}{ Treatment } & \multicolumn{3}{c}{2006} & \multicolumn{2}{c}{$\mathbf{2 0 0 7}$} \\
\cline { 2 - 7 } & DS $^{\mathbf{1}}$ & Efficiency (\%) & DSI (\%) & DS & Efficiency (\%) & DSI (\%) \\
\hline Potassium silicate & $2.4^{\mathrm{a}}$ & 41.4 & $5.8^{\mathrm{a}}$ & $2.0^{\mathrm{a}}$ & 35.7 & $4.6^{\mathrm{a}}$ \\
Sulfur + triadimenol & $2.6^{\mathrm{a}}$ & 44.8 & $7.4^{\mathrm{a}}$ & $1.8^{\mathrm{a}}$ & 32.1 & $4.0^{\mathrm{a}}$ \\
Untreated control & $5.8^{\mathrm{b}}$ & -- & $77.5^{\mathrm{b}}$ & $5.6^{\mathrm{b}}$ & -- & $74.7^{\mathrm{b}}$ \\
LSD & 1.8 & & 3.2 & 1.2 & 2.3 \\
\hline
\end{tabular}

${ }^{1}$ Means within a column followed by the same letter are not significantly different according to Fisher's least significant difference test, $\mathrm{P}=0.05$

staked field tomato.

\section{MATERIALS AND METHODS}

\section{Field trial}

The field experiment was carried out at Agricultural Faculty research station in Tokat during the 2006 and 2007 growing season. Tomato cultivar Alida F1 commonly grown for the fresh market in Tokat was used. Sowing was carried out on 3 February 2006 and 2007 in plug-seedling trays. Transplanting in double rows took place on 7 April 2006 and 2007 at a density of about 29400 plants $\mathrm{ha}^{-1}$. Spacing within rows and between double rows was 0.5 and $1.2 \mathrm{~m}$, respectively. Plants were trained along the plastic thread tide to steel wire stretched over head along the row. Plants were trellised with single stock and trimmed after eighth cluster. Irrigation was applied using a drip method with $4 \mathrm{~L} \mathrm{~h}^{-1}$ drippers placed at 0.4 $\mathrm{m}$ intervals along the irrigation line. Drip irrigation may run for 1 to $2.5 \mathrm{~h}$ at a time, after 1 to 2 day interval, depending on the potential evapotranspiration for research station climate data and crop coefficient. Fertilizers: N (450 kg/ha), $\mathrm{P}_{2} \mathrm{O}_{5}(350 \mathrm{~kg} / \mathrm{ha}), \mathrm{K}_{2} \mathrm{O}(600$ $\mathrm{kg} / \mathrm{ha}), \mathrm{CaO}(50 \mathrm{~kg} / \mathrm{ha}), \mathrm{S}(200 \mathrm{~kg} / \mathrm{ha})$ and $\mathrm{Mg}(50 \mathrm{~kg} / \mathrm{ha})$ were applied throughout the growing period through the drip irrigation system based on the soil analysis results. For insect control, neemazal, yellow and blue stick traps were used. Experimental design was randomized block design with four replications. The treatment program was applied at 12-day intervals from June 7th to August 18th in 2006 and June 11th to August 24th in 2007. During both seasons, natural inoculum occurred as a source of the disease and no extra inoculum was necessary. A list of treatments and concentrations is given in Table 1. Ten centrally located plants were rated for disease severity 12 days after the last application. Leaves from nodes 3 to 4,7 to 9 and 12 to 14 , corresponding to low, intermediate and high heights, were evaluated for disease severity. Disease severity (percentage of the leaf surface covered with powdery mildew symptoms) was evaluated based on the scale of 0 to 6 (Yan et al., 2006); where: 0, no visible pustule; 1, pustules on less than $1 \%$ of leaf surface; 2,1 to $5 \%$ leaf surface covered with pustule; 3, 6 to $20 \%$ leaf surface covered with pustule; 4, 21 to $40 \%$ leaf surface covered with pustule; 5,41 to $60 \%$ leaf surface covered with pustule; 6 , more than $60 \%$ of leaf surface covered with pustule. Disease severity index was determined using following Formula: $\{(0 A+1 B+2 C+3 D+4 E+5 F+6 G) / 6(A+B+C+D+E+F+$ G) $\times$ x 100 , where $A, B, C, D, E, F$ and $G$ are the number of leaves with the disease index scores of $0,1,2,3,4,5$ and 6 , respectively (Yan et al., 2006).

\section{Statistical analysis}

The data were analysed using analysis of variance (ANOVA) test. The means of treatments were grouped on the basis of Fisher's least significant difference (LSD) at the 0.05 probability level. The software SAS was used to conduct all the statistical analysis.

\section{RESULTS}

Applications of potassium silicate $\left\{\mathrm{K}_{2} \mathrm{SiO}_{3}(200 \mathrm{mg} / \mathrm{L})\right\}$ and the alternation of systemic fungicide Bayleton WP 5 (Triadimenol (25 mg/L)) and Thiovit $80 \%$ WP (sulfur $(2,4 \mathrm{~g} / \mathrm{L}))$ with 12 day interval were highly protective against powdery mildew, as compared with the control, and potassium silicate caused no damage to plant tissue at a concentration of $100 \mathrm{~g} / \mathrm{L}$. In 2006 growing period, five applications of either $\mathrm{K}_{2} \mathrm{SiO}_{3}$ or Bayleton WP 5 alternate with Thiovit $80 \%$ WP resulted in DSI of 5.8 and $7.4 \%$, respectively. Average disease severity in the control plots were 5.8 in 2006 growing period, but for $\mathrm{K}_{2} \mathrm{SiO}_{3}$ plots, it was only 2.4 , indicating that foliar spray of $\mathrm{K}_{2} \mathrm{SiO}_{3}$ significantly suppressed powdery mildew (t-test; $\mathrm{P}<0.05$ ). On the other hand, there was no significant difference between $\mathrm{K}_{2} \mathrm{SiO}_{3}$ treatment and Bayleton + sulfur treatment. Similar results were obtained in 2007 (Table 2). The 
disease severity indexes (DSI) were 77.5 and $74.7 \%$ in control plots in 2006 and 2007, respectively and were significantly different $(\mathrm{P}<0.05)$ from those in the $\mathrm{K}_{2} \mathrm{SiO}_{3}$ plots with 5.8 and $4.6 \%$ in 2006 and 2007 , respectively. Also, there was no significant difference between DSI of $\mathrm{K}_{2} \mathrm{SiO}_{3}$ treatment and fungicide treatment (Table 2).

\section{DISCUSSION}

The results demonstrated that five times application of $\mathrm{K}_{2} \mathrm{SiO}_{3}$ with 12 days interval significantly reduced the severity of tomato powdery mildew. The difference between $\mathrm{K}_{2} \mathrm{SiO}_{3}$ and fungicide treatment was not significant and both treatment reduced powdery mildew severity on tomato leaf. The results of the present study are in agreement with similar studies in cucurbits where foliar and root applications of $\mathrm{Si}$ reduced the disease severity of powdery mildew developing in cucumber, muskmelon and zucchini squash (Menzies et al., 1992). Powdery mildew severity in grape leaves was reduced to $11 \%$ of the control leaves when foliar Si sprays were used (Bowen et al., 1992). Also, foliar application of soluble Si reduced the powdery mildew severity of common beans (Rodrigues et al., 2005a) and soybeans (Rodrigues et al., 2005b). Foliar application of potassium silicate, as a source of soluble silicon, decreased angular leaf spot (Pseudocercospora griseola (Sacc.) Crous and U. Braun) severity on beans at more alkaline $\mathrm{pH}$ (Rodrigues et al., 2005a). In powdery mildew of wheat, Bélanger et al. (2003) reported a suppressive effect of silicon and its mode of action against powdery mildew on wheat. A possible effect of foliar application of $\mathrm{Si}$ sources on diseases control might be explained by the establishment of a physical barrier on the host tissue (Samuels et al., 1991; Bowen et al., 1992), although on bean anthracnose (Colletotrichum lindemuthianum (Sacc. and Magnus) Briosi and Cavara), Si applied on foliage was effective even without establishing a physical barrier (Moraes et al., 2006). Thus, increased plant resistance to diseases through $\mathrm{Si}$ treatment is associated with active and/or passive mechanisms (Datnoff et al., 2007). Ghanmi et al. (2004) and Rodrigues et al. (2004) reported that plant's defense mechanisms have been triggered by silicon. For this reason, we thought that liquid potassium silicate, that is, soluble silicon, may play a role not only as a physical barrier, but also as resistance inducer in plants.

Further studies are necessary to elucidate the mechanisms that allow potassium silicate to reduce powdery mildew disease severity on tomato leaf.
Be'langer RR, Benhamou N, Menzies JG (2003). Cytological evidence of an active role of silicon in wheat resistance to powdery mildew (Blumeria graminis f. sp.tritici). Phytophatology, 93: 402-412.

Bowen P, Menzies J, Ehret D (1992). Soluble silicon spray inhibit powdery mildew development on grape leaves. J. Am. Soc. Horticult. Sci. 117: 906-912.

Datnoff LE, Rodrigues FA, Seebold KW (2007). Silicon and Plant Disease. In: Datnoff LE, Elmer WH, Huber DM (Eds.). Mineral nutrition and plant disease. Saint Paul MN. APS Press, pp. 233-246.

Epstein E (1999). Silicon. Ann. Rev. Plant Physiol. Plant Mol. Biol. 50: 641-664.

Ghanmi D, McNally DJ, Benhamou N, Menzies JG, Belanger RR (2004). Powdery mildew of Arabidopsis thaliana: A pathosystem for exploring the role of silicon in plant-microbe interactions. Physiol. Mol. Plant Pathol. 64(4): 189-199.

Kanto T, Miyoshi A, Ogawa T, Maekawa K, Aino M (2006). Suppressive effect of liquid potassium silicate on powderymildew of strawberry in soil. J. Gen. Plant Pathol. 72: 137-142.

Lee JS, Park JH, Kim SK (2000). Effect of soluble silicon on the severity of powdery mildew (Sphaerotheca fuliginea) in cucumber leaves. J. Korean Soc. Hort. Sci. 41: 356-360.

Menzies J, Bowen P, Ehret D, Glass, ADM (1992). Foliar applications of potassium silicate reduce severity of powdery mildew on cucumber, muskmelon, and zucchini squash. J. Am. Soc. Horticult. Sci. 117: 902-905.

Moraes SRG, Pozza EA, Alves E, Pozza AAA, Carvalho JG, Lima PH, Botelho AO (2006). Efeito de fontes de silício na incidência e na severidade da antracnose do feijoeiro. Fitopatologia Brasileira. 31: 69-75.

Ozan S, Maden S (2006). Powdery mildews pathogens seen on tomato. Selcuk University. J. Agric. 20: 126-135.

Pasche JS, Wharam CM, Gudmestad NC (2004). Shift in sensitivity of Alternaria solani in response to Qol fungicides. Plant Dis. 88: 181187.

Reynolds AG, Veto LJ, Sholberg PL, Wardle DA, Haag P (1996). Use of Potassium Silicate for the Control of Powdery Mildew [Uncinula necator (Schwein) Burrill] in Vitis vinifera L. Cultivar Bacchus Am. J. Enol. Viticulture, 47: 421-428.

Rodrigues FA, McNally DJ, Datnoff LE, JonesJB, Labbe C, Benhamou $\mathrm{N}$, Menzies JG, Belanger RR (2004). Silicon enhances the accumulation of diterpenoid phytoalexins in rice: $A$ potential mechanism for blast resistance. Phytopathology, 94: 177-183.

Rodrigues FA, Duarte HSS, Korndörfer GH, Wordell Filho JA, Zambolim L (2005a). Effect of foliar application of postassium silicate on angular leaf spot development on beans. Proceedings of the III Silicon in Agriculture Conference.

Rodrigues FA, Uberlândia MG, Duarte HSS, Korndörfer GH, Zambolim $L$ (2005b). Effect of foliar application of postassium silicate on Asian soybean rust development on soybean. Proceedings of the III Silicon in Agriculture Conference.

Samuels AL, Uberlândia MG, Glass ADM, Ehret DL, Menzies JG (1991). Mobility and deposition of silicon in cucumber plants. Cell Environ. 4: 485-492.

Yan Z, Dolstra O, Prins TW, Stam P, Visser PB (2006). Assessment of partial resistance to powdery mildew Podosphaera pannosa in a teraploid rose population using a spore suspension inoculum method. Eur. J. Plant Pathol. 114: 301-308.

Yildirim A, Onogur E, Irshad M (2002). Investigations on the Efficacy of some Natural Chemicals against Powdery Mildew [Uncinula necator (Schw.) Burr.] of Grape. J. Phytopathol. 150: 697-702.

\section{REFERENCES}

Anonymous (2007). Turkish Statistical Institute, p. 230. 